\title{
Article
}

\section{The 'caged torch procession': Celebrities, protesters and the 2008 Olympic torch relay in London, Paris and San Francisco}

Horne, John David and Whannel, Garry

Available at http://clok.uclan.ac.uk/6527/

Horne, John David ORCID: 0000-0003-4389-8204 and Whannel, Garry (2010) The 'caged torch procession': Celebrities, protesters and the 2008 Olympic torch relay in London, Paris and San Francisco. Sport in Society, 13 (5). pp. 760-770. ISSN 1743-0437

It is advisable to refer to the publisher's version if you intend to cite from the work. http://dx.doi.org/10.1080/17430431003650950

For more information about UCLan's research in this area go to http://www.uclan.ac.uk/researchgroups/ and search for <name of research Group>.

For information about Research generally at UCLan please go to http://www.uclan.ac.uk/research/

All outputs in CLoK are protected by Intellectual Property Rights law, including Copyright law. Copyright, IPR and Moral Rights for the works on this site are retained by the individual authors and/or other copyright owners. Terms and conditions for use of this material are defined in the policies page. 
The 'caged torch procession': celebrities, protesters and the 2008 Olympic torch relay in London, Paris and San Francisco ${ }^{1}$

John Horne

Professor of Sport and Sociology

University of Central Lancashire

Preston, PR1 2HE, UK.

JDHorne@uclan.ac.uk

Garry Whannel

Professor of Professor of Media Cultures

University of Bedfordshire

Luton, UK.

Garry.Whannel@beds.ac.uk

For 'Documenting the Beijing Olympics', a Sport in Society Special Issue to be edited by D. Martinez \& K Latham

5928 words inclusive 
The 'caged torch procession': celebrities, protesters and the 2008 Olympic torch relay in London, Paris and San Francisco

\begin{abstract}
Along with the opening and closing ceremonies one of the major non-sports events associated with the modern Olympic Games is the torch relay. Although initiated in 1936, the relay has been subject to relatively little academic scrutiny. The events of April 2008 however will have cast a long shadow on the practice. This paper focuses primarily on one week (6-13 April) in the press coverage of the 2008 torch relay as the flame made its way from London to Paris in Europe and then to San Francisco in the USA. It discusses the interpretations offered in the mediated coverage about the relay, the Olympic movement, the host city and the locations where the relay was taking place, and critically analyses the role of agencies, both for and against the Olympics, that framed the ensuing debate.
\end{abstract}




\section{The 'caged torch procession': celebrities, protesters and the 2008 Olympic torch relay in London, Paris and San Francisco}

\section{Introduction}

Any discussion of how a sports mega-event has been represented - visually, aurally or in print - raises questions of selection, representation and meaning. As the organisers of the symposium suggest, certain questions - concerning the key stories, their dramatisation, the construction of heroes and villains, the human interest angles and conflicts (political or otherwise) - are germane to an account that attempts to consider the ways in which a megaevent is inscribed into history. What was the impression produced and communicated by representations of aspects of the Beijing Summer Olympic Games? Here we focus on one of the key stories occupying media space for several months before the opening ceremony on $8^{\text {th }}$ August - the torch relay.

Along with the opening and closing ceremonies one of the major non-sports events associated with the modern Olympic Games is the torch relay. Although initiated in 1936, the relay has been subject to relatively little academic scrutiny. This paper focuses primarily on one week (6-13 April) in the press coverage of the 2008 torch relay as the flame made its way from London to Paris in Europe and then to San Francisco in the USA. It discusses the interpretations offered in the mediated coverage about the relay, the Olympic movement, the host city and the locations where the relay was taking place, and critically analyses the role of agencies, both for and against the Olympics, that framed the ensuing debate.

Between March and August 2008 the relay attracted clashes involving pro-Tibet and proChinese government supporters, human rights activists, and others wanting to demonstrate their support for or against the Beijing Olympic Games. The lighting of the Olympic cauldron by Li Ning on 8 August appeared to mark an end to the 'long running' political controversy surrounding the torch relay and, implicitly at least, could be seen as shifting attention away from politics to sporting and economic considerations - inaugurating as it did the sports events themselves and for some commentators reflections on their likely impact on the relative economic fortunes of Adidas, Nike or Li Ning's own brand of sportswear and equipment. 
It is possible to use many different theories to analyse the modern Olympic Games as one of the chief vehicles of the "society of the spectacle", as a "pseudo event", or as a feature of the "culture industry". ${ }^{2}$ But these approaches have the tendency to formalise the properties of the events and rob them of specific content. As Whannel notes they tend to open a gap "between the multiple hybrid complexities of lived experience and the symbolic constructions of media representation". ${ }^{3}$ Hence it is useful to recall, as Roche suggests, that studying mega-events in the round requires at least two levels of analysis - structural (or formal) and phenomenological (or lived) considerations. ${ }^{4}$ The torch relay and its representation also offer a case study through which to examine politics and media associated with the mega-event. If we consider, as Price and Dayan do, ${ }^{5}$ that the Olympics are a "media event" then we can approach the torch relay as a very good example of what happens when "media events become marked by efforts by free riders or interlopers to seize the opportunity to perform in a global theatre of representation". ${ }^{6}$ What Price alerts us to is the political significance of the modern Olympic Games - the place they hold as a "platform" - a "mechanism that allows for the presentation of information and its transmission from a sender to a receiver" ${ }^{7}$ - on a global scale. As Short suggests the Summer Olympics are "global spectacles, national campaigns and city enterprises" ${ }^{8}$ at one and the same time. They are "'glocal' events of national significance”. 9

The torch relay is no ancient Olympian ritual, but rather a classic example of the 'invention of tradition', devised in this instance by the Nazis for the 1936 Olympic Games to emphasise the supposed "spiritual bond" between the German fatherland and the sacred places of Ancient Greece. A flame was lit in the stadium for the first time in the 1928 Olympic Games in Amsterdam, and again in 1932 in Los Angeles, but the first time the flame was lit at Olympia and conveyed by relay was 1936. The Ancient Greeks did have relays carrying torches but there is no evidence that they ever did so in connection with the Olympic Games.

In short, the relay was invented in order to glorify the Nazi regime and assert its connection to Greek civilization as a sort of legitimating trope. Krupp, the German arms producer created and sponsored the torches. And while in Vienna, Austrian Nazis greeted the torch 
with cries of 'Heil Hitler' and demonstrated against Jewish members of the Austrian Olympic team, with a resultant five hundred arrests; in Prague street fighting broke out between Sudetan Germans and Czechs. The Nazi anthem, the 'Horst Wessel Lied' was played in Ancient Olympia when the flame was lit. The song, which contains the line "Already millions are looking to the swastika, full of hope” was also sung at the Opening Ceremony. ${ }^{10}$

The concept of the torch travelling around the world is another invention of tradition but far more recent - it was only introduced at the 2004 Olympic Games. Prior to that the torch usually took the most direct route: while there were occasional ceremonies on route, the relay itself was largely restricted to Greece, the host country, and any other countries immediately on route. In 2004, for the first time, the torch took a more elaborate and circuitous route visiting countries around the world. While this all contributes to advance publicity for the Games, not always with perfect success, the main reason for the change is sponsorship. The Olympic Games is unique amongst major events in allowing no arena advertising. Consequently, despite paying huge sums to join the Olympic Sponsorship programme, the sponsoring companies get no access to the global television audience. The global torch relay provides a set of mobile photo opportunities around the world, ensuring exposure of the brand name across media for a month or more.

As a global spectacle, consumed by audiences around the world, the Olympic Games become a focal point for political contestation. The hosts utilise the event to boost the image of their city and their nation; the sponsors to promote and enhance brand awareness and brand image, and campaigners use it to gain media coverage for their issues. The torch relay presents an opportunity for subversion or "hijacking" by otherwise marginal actors. In this case "piggybacking" or even "piggyjacking" 11 might be considered more appropriate ways of referring to the situation where actors, "finding a platform that has proven highly successful in establishing a major constituency for one purpose ... then convert that constituency to a different, unintended objective". ${ }^{12}$ Such associations between Olympic rituals and ceremonies can be deemed more or less legitimate. The recent commercialization of the relay - in 2008 heavily underpinned by the Chinese company Lenovo and other companies sponsoring the Games- can be seen as a contractually legitimate, as opposed to an 'ambush', form of marketing. 
The torch took about a year to design to the specifications that would keep it burning on its varied journey around the world, said David Hill, vice president of corporate identity and design for Lenovo, the computer manufacturing firm that designed the torch and a main sponsor of the torch relay. ${ }^{13}$

For the costs of the creation of the event to be borne by one group, and for the benefits (or at least mediation of a cause) to be obtained by others is an example of platform "hijacking”. The Olympic Games is a media platform with an assumed dominant narrative; the IOC, Games organisers, sponsors and athletic federations attempt to defend the narrative against counter narratives. Today this involves intense management of the narrative, although this does not guarantee success as we will see. A problem for the Olympics is that there is some ambiguity over the ownership of the Olympic Games platform and the narrative. Who owns it?: Is it the IOC, the organising committee, the host city or nation, or the sponsors? There are complementary and competitive uses of the narrative, the former as in advertising by the Korean National Tourism Agency during the summer of 2008 attempting to persuade tourists to continue their stay in East Asia by visiting Seoul; the latter through the development of the alternate phrase 'The Genocide Games'. Some would see the division between the idealists, who are expressing internationalism, sentimentalism, global solidarity, and merchants, who are focussing on the event as a showcase for the global sports entertainment industry, as a major faultline in the contemporary Olympics. Yet "promotionalism” in global civil society is unstable. ${ }^{14}$ Hence the Olympic Games, as both a platform and a discourse, are unstable too.

\section{The 2008 'journey of harmony'}

'Human rights shadow over Beijing games' 15

“Taiwan rejects China’s planned route for Olympic torch. ${ }^{16}$

From the start of the decision to award the games to Beijing in 2001, and the commencement of the Beijing Olympiad in 2004, there was controversy just as there had been in 1993 when the Beijing bid was marginally defeated by Sydney and behind which lay attempts to cast the Chinese bid in as bad a light as possible. In particular, regarding the torch relay, in 2008 there was disagreement over the route - involving the 'two Chinas' issue, Tibet, and Mount Everest - for at least a year before it happened. Celebrities contributed to a call for a boycott 
of the Beijing Games on the basis of human rights abuses in China and China's relations with Sudan and Darfur in particular. Prominent were actors Richard Gere and Mia Farrow, the latter whose arguments lead to the withdrawal of Steven Spielberg from producing the opening and closing ceremonies. ${ }^{17}$ Archbishop Desmond Tutu later called for a boycott of the opening ceremony "Boycott opening of Olympics urges Tutu"18 and appeared to receive some support from European political leaders (for example, Angela Merkel and Gordon Brown). On 24th March 2008 the torch was lit - and British TV covered the demonstration by members of Reporters without Borders at the ceremony in Olympia. The torch was then taken around Greece to Athens from where it was transferred to Beijing on 31 March.

\section{London-Paris-San Francisco}

The torch came to London 134 days before the Beijing Olympics opened. London's thirtyone mile route turned into a procession in which the torch was sometimes shielded by up to three ranks of guards - blue tracksuit wearing flame attendants (or 'flame retardants' as one wag renamed them), later to be revealed as members of the Chinese People's Armed Police the London Metropolitan police on foot, and police as outriders on bicycles, horses and motorbikes. ${ }^{19}$ It appeared, from the live coverage broadcast on TV, that anyone getting in the way or near the torch was either swatted aside by the police or arrested - there were thirty five arrests by mid-afternoon. There were changes from the scheduled route - for example in Fleet Street the torch was transferred to a bus and taken to St Paul's. As Mihir Bose, the BBC's first sports news editor commented, instead of a view of the torch most people got a view of a police operation. By the time it was reaching its destination - the O2 Arena - Bose referred to it live on air as a 'caged torch procession'. ${ }^{20}$

As the relay made its way across London the BBC TV News 24 channel covered events as they unfolded. Occasionally athletes were called upon to comment on the situation. Olympic medal winner Duncan Goodhew stated that the Olympics was about excellence, equity and a force for good; the actions seen on the TV screen did not reflect well on the UK. ${ }^{21} \mathrm{TV}$ presenter and former tennis professional Sue Barker said that the event had been 'hijacked' by a series of pressure groups. ${ }^{22}$ Lord Sebastian Coe, an Olympic champion, former conservative MP and director of LOCOG, said that most of the legs of the relay passed off without much incident. Athlete Kelly Holmes promoted a view very similar to the one put 
forward by Goodhew - which raised a suspicion that there was a prepared 'statement' for athletes and supporters to convey the preferred Olympic narrative about fellowship, internationalism and its general benefit to humanity. ${ }^{23}$

\section{Print Media Coverage of the Torch Relay 6 - 13 April 2008}

The agenda was set before the arrival of the torch in Europe in April by the television and print media coverage of the lighting ceremony and political developments in Tibet, which established the disruption of the torch relay as the main narrative theme: "New clashes in Tibet on eve of Torch's arrival in UK”. ${ }^{24}$ Then when it arrived in London the torch relay stimulated the following headlines: “Arrests, fights, jeering: Olympic relay sparks anger and chaos" and "OLYMPIC SPIRIT COMES TO BRITAIN". ${ }^{25}$ Below the second of these headlines there were three pictures of police struggling with demonstrators with the words:

Faster! Officers rush to prevent protester from extinguishing the flame

Higher! Additional security called in after man attempts to grab torch

Stronger! Police get tough to keep the relay on course for Beijing ${ }^{26}$

The general verdict of the British press was damning - the event was portrayed widely as a chaotic farce: "the event descended into chaos"; "OLYMPIC MAYHEM" and "Organisers hoped for a feelgood day of fun. Instead there was an atmosphere of tension, indecision and a siege mentality...Celebrity torch bearers ran a gauntlet of abuse and threats....Millions worldwide saw shocking scenes unfold”. ${ }^{27}$ The comments continued: "OLYMPIC RUN TURNS INTO FARCE: Angry demonstrators turned the Olympic torch procession into a farce yesterday as Britain's Olympic prestige was damaged by scuffles on its route through London". ${ }^{28}$ And: "our Olympic showpiece ended in violence and farce... a combination of sinister and slapstick...bizarre scenes...embarrassing fiasco...was beamed around he world...surreal circus...Chinese goon army... The burly minders”. ${ }^{29}$

The Evening Standard - the only paid for daily London newspaper - linked events to a negative view of the UK and the capital city. The front page headline 'THE SHAMING OF LONDON' over a picture of a Malaysian family sleeping in a cardboard box in Heathrow Terminal 5 was above three sub headings which read: 
T5 travellers forced to spend night in cardboard boxes

Olympic torch fiasco descends into a war of words

No wonder these visitors swore: 'Bloody England”30

In editorials the perspective varied, according to who was blamed for the events. The Daily Mail and the Evening Standard blamed the IOC for choosing China:

When it awarded the Games to China it extracted a number of commitments from the Chinese government over human rights. It has done nothing like enough to make clear that, particularly in respect of Tibet, these commitments have not been honoured. ${ }^{31}$

The real embarrassment is that the International Olympic Committee seems to have no moral compass in deciding who gets the Games. China's regime doesn't deserve this honour. Can the IOC be surprised when the public says so? $?^{32}$

The Sun, by contrast, regarded it as a victory for the traditions of protest and for the police:

\section{FREEDOM WINS}

We are lucky to live in a country that values its citizens right to hold lawful peaceful protests. And police must be congratulated for their skill in allowing that to happen while preventing those with unlawful intentions from putting the flame out or injuring torch bearers. ${ }^{33}$

The role of the blue tracksuited torch guards was particularly controversial attracting headlines such as: "Paramilitaries guard torch relay". ${ }^{34}$

The Greater London Authority, which co-organised the event, said: "They were brought over by the Beijing organising committee. They were the responsibility of Beijing." A spokesman insisted it was the British Olympic Association which was responsible for dealing with the Chinese. But the BOA's spokesman said: "They were nothing to do with us. The relationship they had with the Met and the GLA was the responsibility of the GLA." The Met Police said 
the Chinese guards had "no executive powers" in Britain and were simply there to protect the torch. Privately, police were said to be furious as officers were made to look ridiculous, jogging along in cycle helmets and holding hands to form a chain around the bearers. MPs said the fiasco made Britain a laughing stock. But Olympics Minister Tessa Jowell said: "I don't think it made us look bad. The police did the best job they could." 35

In general, the various implicated organisations did their best to deflect blame elsewhere. When the torch continued on its journey in Paris, amidst "waves of chaos" 36 according to the there was an almost tangible sense of relief in the manner in which the British press suggested the French had done no better and possibly worse in policing the protests:

\section{SACRE BLEU}

THE Olympic torch was snuffed out four times yesterday as it was relayed through Paris - before eventually being put on a BUS to shield it from antiChinese mobs. ${ }^{37}$

"Paris demonstrators force flame to be extinguished"38

\section{MORE OLYMPIC CHAOS AS PROTESTS SNUFF OUT TORCH}

THE Olympic torch relay descended into French farce yesterday as protesters forced officials to abandon the Paris leg of the parade. Chinese minders extinguished the "eternal flame” four times in as many hours so demonstrators could not get near it. ${ }^{39}$

Yesterday the mayhem continued in Paris. Security officials extinguished the torch four times before putting it in a bus for the final stages. ${ }^{40}$

The flame had to be extinguished three times amid safety concerns. ${ }^{41}$

The relay was now being subject to ever enhanced security and growing restrictions in scale. By the time it arrived in San Francisco it had become a running story in the world's media, a soap opera in which the next episode was keenly anticipated. The Guardian reported that 
“All police leave has been cancelled” and said “...officials in San Francisco brace themselves for a repetition of the tumultuous scenes in Paris and London". ${ }^{42}$ The New York Times reported that a heavy law enforcement presence was expected, and that there would be a lowaltitude, no-flight zone over the route. ${ }^{43}$ Other papers reported: “Olympic-Torch Protestors Given Slip in San Francisco" and "Torch Relay takes detour”. ${ }^{44}$ The events of 6-11 April 2008 were summed up by the Guardian Weekly: “Torch’s journey descends into chaos”. 45

\section{Spin, Counter-spin and fall-out from the "Tour de Farce"}

In the immediate wake of high profile media events, such as the 'caged torch procession' or “Tour de Farce” as The Guardian named it, ${ }^{46}$ key actors battle to establish their own frames and definitions of the situation as dominant. Famous names were reported as supporting the protests. Richard Gere attended a vigil in San Francisco and said that by parading the torch in Tibet China was trying to give a false picture of peace and harmony there. ${ }^{47}$ Celebrities were also participants in the torch relay and the British press emphasised their encounters with demonstrators:

"Stars are pounced on by protesters as London Olympic torch parade turns ugly.

TV's Konnie Huq was set upon by a Free Tibet campaigner who tried to rip the torch from her hands. Olympic champ Denise Lewis was charged at by several activists while Sir Clive Woodward had his path blocked by a mob. Cricket star Kevin Pietersen had to be ushered away when campaigners threatened to swamp him.... Amid endless booing and hissing, the stars - including Denise Van Outen, Paula Radcliffe, Arsenal's Theo Walcott and the Sugababes - were continually interrupted along the route", ${ }^{48}$

A BBC journalist based in China suggested that the normal response to difficult news in China was to delay, condemn and then deride. On this occasion there were other opportunities to counter the negative news: the foiling of a terrorist plot, the discovery of a heroine (Jin Jing), and concerns about western media coverage of China by the ambassador to London as indicated by the headlines below:

China foils Olympic terror plot.

Western press demonises China. 
Chinese Ambassador warns of backlash. ${ }^{49}$

The western media generally has long operated with a restricted and monolithic vision of China - overlooking tensions between progressives and reactionaries, liberalising and conservative elements, central and local government. As a result an excessively static image of China is constructed, de-emphasising the very rapid pace of change and adjustment that Chinese society is undergoing. The media in China, whilst subject to control and regulation, is also at times a resource for combating corruption. ${ }^{50}$ Limited and stereotypical images and conceptions of East Asian (and other non-western) societies is an identified feature of western media coverage of sports mega-events, as much as political, economic and social issues. Wasserstrom identified the polarised vision of China routinely constructed in the US media - revolving between the nightmare and the dream of 'Big Bad China and the Good Chinese'. ${ }^{51}$

Celebrity involvement - featuring children's’ writers and Hollywood actors - continued with the coincidence of 'Global Day for Darfur' on 13 April: "Rowling demands action in Darfur". ${ }^{52}$ Another spin off was the concern that the protests might switch to sponsors of the relay, “Olympic Torch Uproar Could Burn Lenovo” and "Follow the money: Olympic protest movement turns its sights on to sponsors”. ${ }^{53}$

\section{Conclusions}

In the build up to an Olympic Games the media coverage is often focussed on two central questions: 'will it go over budget?' and 'will the facilities be ready in time?' The answer to both questions is usually 'yes'. Other newsworthy possibilities depend on the specific location and political developments at the time. In terms of news management by the organising committee, the months leading up to the games, are the most perilous period, in which negative stories can easily turn in to front page dramas, as occurred in 2008 during the torch relay. After the games commence, by contrast, there is a massive turning inward of the media to events in the arenas and the stadia.

What does this account tell us about the coverage of the build up to Beijing Olympic Games? 
Hosting the Olympic Games (and other mega-events) is a political act; public events and institutions involving decisions over the allocation of resources have political dimensions. They require consideration of the distribution of power, struggles and who gains from the situation. Narratives associated with hosting mega-events, and the Summer Olympic Games in particular, in East Asia have included the following: that it provides an opportunity to catch up or modernize, an opportunity to challenge (Western) modernity, and an opportunity to project distinctive forms of hybrid or hyper- modernity. Whether in the form of overt politics, protest, or promotion, hosting a sports 'mega' provides an opportunity for power plays by states, civic authorities, and groups for and against the event. Attempts to hijack the torch relay provoked a nationalist response, when previously the Olympics were being promoted as an internationalising event. The Western media tended to portray the events of London, Paris and San Francisco as peaceful protests against a repressive regime and a military crackdown. The Chinese media eventually responded by considering the events as violent acts against innocent people (especially the disabled 'heroine' of Paris, Jin Jing) requiring the restoration of order and stability. In this way different actors sought to impose their frames of reference on the situation. Who has the power to define dominant narratives and frames remains a crucial question.

So what does this tell us about the politics of sports mega-events and the Olympic Games especially? The Olympic Games attract attention globally for several months before the twoweek event itself. Political issues get attached to it by virtue of it being a media event and platform. Nations, and since the late 1980s, cities as part of nations, put their power, competence and reputation on the line. Cities and nations can have alternative intentions. Olympic boosters and Olympic sceptics - politicians, sports, human rights, and celebrities have multiple interests when engaging in the politics of the Olympics. The Olympic Games deploys invented traditions - the oath, the village, the torch relay. The last serves to advertise and promote the Olympic Games, the host city, nation and the IOC. The expanded torch relay gave Olympic sponsors an opportunity to promote themselves away from the still regulated stadia environment. The Olympics provides an opportunity to 'piggyjack' an event nonetheless. 
What does this tell us about the media? Gatekeeping, agenda setting, framing and constructing news remain key aspects of the mediation of any event and mega-event. Power and influence to shape the agenda - and construct the story - remain tied to large media organisations despite the internet and the emergence of heterogeneous voices. Live coverage in key locations means the media agenda alters as event develops. A person on the spot will not always be best informed about the progress of a news story. ${ }^{54}$ Media representations are more central to contemporary politics than what happens in the street. Impression management is the new battleground. Hijacking or piggybacking will continue to pose problems for dominant narratives. The effect of vortextuality is dangerous for public relations, spin doctors and media managers. ${ }^{55}$ The torch became a symbol of state power needing great protection. If the relay had been differently organised with different groups of people surrounding it (women, people of the world, children) a different image of it could have been constructed. Better image management and planning, based on a better understanding of the how the media works in specific instances might have averted or at least reduced the impact of the 2008 torch relay fiasco. ${ }^{56}$

All of this points out that the impact of the erosion of the public-private distinction, the declining powers of regulation and censorship, and the growth of celebrity culture, combined with the expansion of the media and the increase in the speed of circulation have produced the phenomenon Whannel referred to as "vortextuality". ${ }^{57}$ The various media constantly feed off each other in a process of self-referentiality and intertextuality. In an era of electronic and digital information exchange, the speed at which this happens has become very rapid. Certain super-major events come to dominate the headlines. It becomes temporarily difficult for columnists and commentators to discuss anything else. They are drawn in, as if by a vortex. There is a short term compression of the media agenda. Other topics either disappear or have to be connected to the vortextual event. In the midst of a vortextual moment, cartoons, radio phone-ins, celebrity columnists, news magazines, cultural commentators, and letter pages, are all drawn into the central topic. Among examples of this effect are funerals (the death of Princess Diana), trials (the verdict announcement in the Michael Jackson trial), and celebrity weddings (e.g. of David Beckham and Victoria Adams). 
What does this tell us about the future? The Olympic Games are composed of diverse elements: modernity and tradition, festival and global spectacle, peace and internationalism, discipline and surveillance, youth, the IOC and commercial sponsors. It is difficult to keep opportunities for protest secure without risking poor image and depleting reputation further like scandals - and maybe this is why no petitioners for protests were allowed in Beijing in 2008. ${ }^{58}$ More, not less, difficult to predict is what will happen in the run up to London 2012 and beyond, but the spectacle is likely to become more closely monitored, policed and kept under surveillance, as the following newspaper headlines suggest.

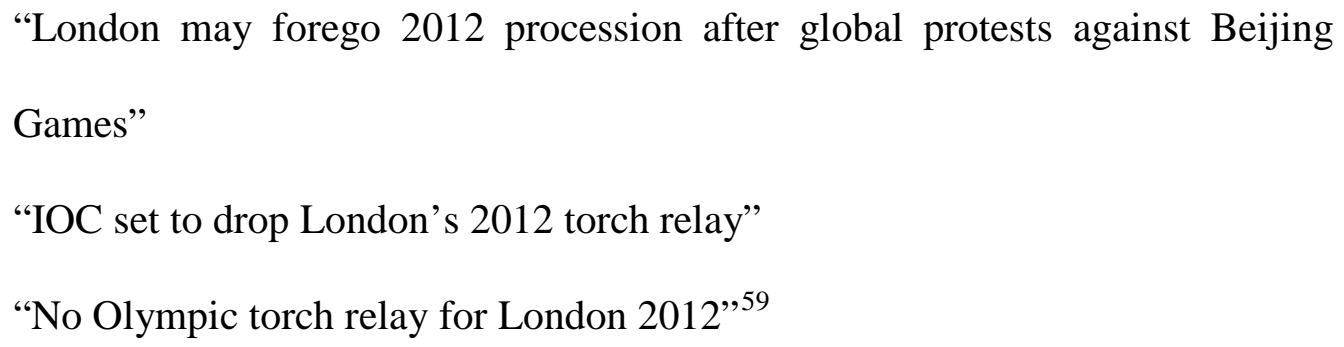

In the age of risk society where 'subpolitics' - motivated by ethical considerations, a decentered network form of organization and a pluralistic tactical focus - are more evident than institutionalized politics, ${ }^{60}$ global social movements seek to develop new worlds and new sport and thus contribute to global civil society. ${ }^{61}$ For authorities, including sports megaevent organizers, risk society raises questions about the calculation of spectacle and the need for enhanced impression management. In this context the Beijing Games and other Olympic Games will remain a field of contestation "in which conflicting discourses, constituted by different regimes of truth produced by various interest groups, vie for global attention. ${ }^{62}$ Media events such as the Olympics are "an exploited resource within a political economy of collective attention". ${ }^{63}$ A two-year cycle follows the pattern of the major sports mega-events. Just like the Olympic flame (as opposed to the torch) the global critical consciousness about social justice, social equity and social development cannot be extinguished when events come to an end. Sports mega-events "have become strategic venues" ${ }^{64}$ in political, as well as economic and sporting, terms. 


\section{References}

Adorno, T. \& Horkheimer, M. (1979) Dialectic of Enlightenment. London: Verso.

Brohm, Jean-Marie (1980) Jeux Olympiques a Berlin. Paris: Editions Complexe.

Beck, U. (1992) Risk Society: Towards a new modernity. London: Sage.

Boorstin, D. (1961) The Image. Harmondsworth: Penguin.

Dayan, D. (2008) ‘Beyond Media Events: Disenchantment, Derailment, Disruption’ in Price, M. \& Dayan, D. eds Owning the Olympics: Narratives of the New China Ann Arbor: University of Michigan Press. (pp. 391-401)

Debord, G. (1977) Society of the Spectacle. Detroit: Black \& Red.

Hart-Davis, Duff (1986) Hitler’s Games. London: Century

Harvey, J, Horne, J. \& Safai, P. (2008) 'From “One World, One Dream” to “Another Sport is Possible”: Alter-Globalization, (New) Social Movements and Sport', paper presented at conference "To Remember is to Resist: 40 years of Sport and Social Change", Toronto, 20-22 May 2008.

De Kloet, J., Chong, G.P.L, \& Liu, W. (2008) 'The Beijing Olympics and the Art of NationState Maintenance’ in China aktuell 2/2008 pp. 5-35.

Knight, G. \& Greenberg, J. (2002) 'Promotionalism and Subpolitics’ in Management Communication Quarterly 15/4 pp. 541-570.

Miah, A., Garcia, B. \& Zhihui, T. (2008) '”We are the Media”: Nonaccredited media and citizen journalists at the Olympic Games' in Price, M. \& Dayan, D. eds Owning the Olympics: Narratives of the New China Ann Arbor: University of Michigan Press. (pp. 320-345)

Murray, William, and Arnd Kruger (eds) (2003) The Nazi Olympics. Urbana and Chicago: University of Illinois Press

Price, M. (2008) ‘On Seizing the Olympic Platform’ in Price, M. \& Dayan, D. eds Owning the Olympics: Narratives of the New China Ann Arbor: University of Michigan Press. (pp. 86-114)

Price, M. \& Dayan, D. eds (2008) Owning the Olympics: Narratives of the New China. Ann Arbor: University of Michigan Press.

Roche, M. (2000) Mega-events and Modernity. London: Routledge.

Short, J.R. (2004) Global Metropolitan: Globalizing cities in a capitalist world. London: Routledge. 
Walters, Guy (2006) Berlin Games: How Hitler Stole the Olympic Dream. London: John Murray.

Wasserstrom, J. (2008) 'Dreams and Nightmares: history and U.S. Visions of the Beijing Games' in Price, M. \& Dayan, D. (eds.) Owning the Olympics: Narratives of the New China. Ann Arbor: University of Michigan Press. (pp. 163-184)

Whannel, G. (2002) Media Sport Stars: Masculinities and moralities. London: Routledge. Whannel, Garry (2008) Caught in the Spotlight: Media Themes in the build-up to the Beijing Olympic Games, in Pathways: Critiques and Discourse in Olympic Research, (Ninth International Symposium for Olympic Research), Barney, Robert K.; Michael K. Heine, Kevin B. Wamsley, and Gordon H. MacDonald (eds.). Alberta: International Centre for Olympic Studies.

${ }^{1}$ This article derives from a paper originally drafted for a symposium in London in September 2008 by John Horne and another presented by Garry Whannel in Beijing in August 2008.

${ }^{2}$ See: Debord 1977; Boorstin 1961; Adorno and Horkheimer 1977.

${ }^{3}$ Whannel 2008: 253.

${ }^{4}$ Roche 2000 : 217-235.

${ }^{5}$ Price 2008; Dayan 2008

${ }^{6}$ Price 2008; 86.

${ }^{7}$ Ibid.:87.

${ }^{8}$ Short 2004:86.

${ }^{9}$ Ibid.

${ }^{10}$ For more on the 1936 Games, see Hart-Davis (1986), Brohm (1980) Murray and Kruger (2003) and Walters (2006)

${ }^{11}$ Miah et al 2008: 339 \& 343 n10.

${ }^{12}$ Price op. cit.: 89. 
${ }^{13}$ San Francisco Chronicle 07/04/08.

${ }^{14}$ Knight and Greenberg 2002.

${ }^{15}$ The Guardian 30 August 2004: 5.

${ }^{16}$ Ibid. 27 April 2007: 18. (All newspaper quotations are from The Guardian unless noted otherwise).

${ }^{17}$ See Price 2008.

${ }^{18}$ Ibid. 29 April: 18.

${ }^{19}$ It was later stated that there were 2060 Metropolitan police officers on duty on 6 April at a cost of £746,000 ("Met defends Chinese torch guards Coe said acted like thugs” The Guardian 7 May p. 7).

${ }^{20}$ BBC 1 TV 5.50 pm.

${ }^{21}$ BBC News 243.50 pm.

${ }^{22}$ BBC 1 TV 5.35 pm.

${ }^{23}$ Subsequently confirmed by journalist Richard Williams (The Guardian 8 April 2008 Sport section p. 7).

${ }^{24}$ Op.cit. 5 April: 1.

${ }^{25}$ Op.cit. 7 April: 1; and The Independent 7 April:1.

${ }^{26}$ The Independent 7 April:1

${ }^{27}$ Evening Standard 7 April; The Sun 7 April; The Sun 7 April

${ }^{28}$ Daily Express 7 April

${ }^{29}$ Daily Mail 7 April.

${ }^{30}$ Evening Standard 7 April. 
${ }^{31}$ Evening Standard 7 April.

${ }^{32}$ Daily Mail Editorial 7 April.

${ }^{33}$ The Sun 7 April.

${ }^{34}$ Financial Times 9 April: 10.

${ }^{35}$ Daily Mail 8 April.

${ }^{36}$ International Herald Tribune 8 April.

${ }^{37}$ The Sun 8 April.

${ }^{38}$ Op. cit. 8 April:. 3. Note that it was the torch and not the flame that was extinguished according to other reports.

${ }^{39}$ Daily Express 8 April.

${ }^{40}$ Daily Mail 8 April.

${ }^{41}$ (BBC News bbc.co.uk 11/04/08)

${ }^{42}$ Op.cit. 9 April.

${ }^{43}$ New York Times, 8 April.

${ }^{44}$ Wall Street Journal 8 April: A7; USA Today 8 April: A1.

${ }^{45}$ Guardian Weekly 11 April: 12.

${ }^{46}$ Op. cit. 12 April. 2.

${ }^{47}$ BBC News bbc.co.uk, 9 April.

${ }^{48}$ Daily Mirror 7 April.

${ }^{49}$ BBC News Online 10 April; BBC News Online 13 April; The Guardian 14 April: 11.

${ }^{50}$ Whannel 2008.

${ }^{51}$ Wasserstrom 2008: 179.

${ }^{52}$ BBC New Online 11 April. 
${ }^{53}$ Wall Street Journal p. B1; The Guardian 20 April p. 3.

54 On the day of the London leg of the torch relay GW in London, observing and taking pictures of the torch relay, called JH in Edinburgh to find out what was happening via the BBC TV broadcast. As is often the case it is possible to be too close to an event to fully understand it. The significance lies in what images and words are utilised to narrate the events in the media

${ }^{55}$ Whannel 2002.

${ }^{56}$ Whannel 2008.

${ }^{57}$ Whannel 2002.

${ }^{58}$ Although we have to avoid the double-bind identified by Wasserstrom (2008 p. 179): protests against a regime can be considered as an indication of the repressive nature of a regime; the absence of such protests can equally be interpreted as evidence of just how repressive a regime is!

59 The Guardian 8 April: 3; 6 August 'Sport section’: 1;The Times 6 August.

${ }^{60}$ Knight \& Greenberg 2002; see also Beck 1992.

${ }^{61}$ Harvey et al 2008; Price 2008.

${ }^{62}$ de Kloet et al 2008: 9.

${ }^{63}$ Dayan 2008: 397.

${ }^{64}$ Dayan 2008: 397. 